\title{
Agave juice improves survival and proteolytic activity of Lactobacillus rhamnosus GG during ripening of semi-ripened mexican cheese
}

\author{
Juan RAMÍREZ-GODÍNEZ1, Juan Francisco GUTIÉRREZ-RODRÍGUEZ ${ }^{1}$, Elizabeth CONTRERAS-LÓPEZ², \\ Gabriela Mariana RODRÍGUEZ-SERRANO ${ }^{3}$, Araceli CASTAÑEDA-OVANDO², Judith JAIMEZ-ORDAZ ${ }^{2}$, \\ Luis Guillermo GONZÁLEZ-OLIVARES²* (1)
}

\begin{abstract}
The importance of functional foods added with probiotics and prebiotics is directly related with the promotion of the health benefits of human. In this study the survival of the probiotic Lactobacillus rhamnosus GG in a semi-ripened cheese added with agave juice, was determined. Cheese ripening was carried out at $14{ }^{\circ} \mathrm{C}$ for 35 days. The $\mathrm{pH}$ changes were measured and the hydrolysis of the protein was evaluated through the analysis of free amino groups by the trinitrobenzenesulfonic acid (TNBS) method and SDS-PAGE polyacrylamide gel electrophoresis. At the end of the study, in the symbiotic cheese, the viability of the probotic was increased in two logarithmic cycles (from 6.73 to $8.72 \log$ CFU). A more active proteolytic process was observed with the addition of agave juice, due to the high production of low molecular weight peptides and the concentration of free amino groups $(8.63 \mathrm{mg} / \mathrm{L})$. The $\mathrm{pH}$ did not have a significant difference between the control and the cheese studied. With the obtained results, it is seen that agave juice is an ingredient that can be added to semi ripening cheeses with the objective of improving the survival capacity of probiotic microorganisms, which are used as starters.
\end{abstract}

Keywords: Prebiotic; agave juice; ripened cheese; proteolytic activity; probiotic survival; symbiotic cheese.

Practical Application: Agave juice is an important traditional ancient Mexican beverage with prebiotic potential that can be used as an ingredient in semi-ripened cheese manufacture.

\section{Introduction}

During the last decade, the importance of foods added with probiotics has been demonstrated with benefits that range from the activation of the immune system to mechanisms against diarrheas associated with antibiotics (Orsi \& Zambrini, 2017). A probiotic is defined as a living microorganism that actively improves the health of consumers, balancing the intestinal microflora when they are consumed viable and in sufficient concentrations (from $10^{6}$ to $10^{9}$ colony forming units (CFU / mL) (Vinderola et al., 2019). Recently, new terminology to cover all healthful impacts of live probiotic cells and their derivatives in all possible forms, has been proposed: 'true probiotic', 'pseudoprobiotic', and 'ghost probiotic' (Zendeboodi et al., 2020).

In many cases, oligosaccharides are added to probiotic foods that promote the development and survival of probiotic bacteria (Costa et al., 2019; Jaimez-Ordaz et al., 2018). These oligosaccharides are called prebiotic, which are non-digestible carbohydrates that when are consumed, selectively stimulates the growth of a limited number of bacteria in the colon promoting the survival of probiotic bacteria (Quigley, 2019).

Foods that contain both, probiotics and prebiotics have been defined as symbiotic (Guarner et. al., 2012), this term should be reserved exclusively to products in which symbiosis has been scientifically proven (Sanders et al., 2019) and could be considered as nutraceutical (Sarfraz et al., 2019, Shafi et al., 2019).

Lactic acid bacteria are among the starter cultures used in cheese processing (for both fresh and ripened cheese). These bacteria may have probiotic characteristics, or antibiotic properties inhibiting the growing of pathogenic strains (Prezzi et al., 2020) or even biological properties such as reducing postprandial glycemia (Grom et al., 2020). However, in the particular case of the use of probiotic lactic bacteria, many of these do not survive due to the stress generated by the presence of salts, storage temperatures, among other factors (Chen et al., 2017). Therefore, to make sure that the amount of probiotic lactic acid bacteria is adequate at the time of its consumption, cheeses have been inoculated with high concentrations of microorganisms (between $10^{9}$ to $10^{12} \mathrm{CFU} / \mathrm{mL}$ ) modifying the manufacturing processes to favoring their survival (Farnworth, 2008, Chung \& Kamal-Eldin, 2020).

One of the main factors that affect the viability of probiotic lactic acid bacteria is the presence of oxygen, this because they are mostly facultative anaerobic bacteria. That is why, due to the low mobility of oxygen in cheeses, these matrices favor the survival of probiotic lactic acid bacteria, and prebiotics would

${ }^{1}$ Área Académica de Gastronomía, Instituto de Ciencias Económico Administrativas - ICEA, Universidad Autónoma del Estado de Hidalgo - UAEH, San Agustín Tlaxiaca, Hidalgo, México

${ }^{2}$ Área Académica de Química, Instituto de Ciencias Básicas e Ingeniería - ICBI, Universidad Autónoma del Estado de Hidalgo - UAEH, Mineral de la Reforma, Hidalgo, México ${ }^{3}$ Departamento de Biotecnología, Universidad Autónoma Metropolitana-Iztapalapa - UAM-I, México D.F., México

*Corresponding author: lgonzales@uaeh,edu.mx 
stimulate its selective growth (González-Olivares et al., 2014). That is why; the aim of this work was to determine the effect produced by agave juice on the growth and survival of a probiotic, during ripening of a semi-ripened Mexican cheese.

\section{Materials and methods}

\subsection{Agave juice analysis}

Agave juice was obtained from the scraping of three agaves (Agave salmiana var. "Ayoteco") from Epazoyucan, Hidalgo (Mexico). It was pasteurized in autoclave at $90{ }^{\circ} \mathrm{C}$ for 15 minutes. The carbohydrate concentration was determined according to Jaimez-Ordaz et al. (2018) methodology by High Performance Liquid Chromatography (HPLC) (Lab Alliance, Tokyo, Japan). A 7.8 x 300 mm RNO-oligosaccharide column (Phenomenex, Torrance CA) and a Light Scattering detector (Polymer Laboratories, Amherst, MA). The elution medium was pre-degassed water $\left(\right.$ at $75^{\circ} \mathrm{C}$ ) at a flow rate of $0.3 \mathrm{~mL} / \mathrm{min}$. The run was carried out at a constant temperature of $75^{\circ} \mathrm{C}$ and the detector was maintained at a misting temperature of $110^{\circ} \mathrm{C}$.

\subsection{Mexican semi-ripened cheese processing}

Lactobacillus rhamnosus GG was used as starter microorganism to produce the cheese. It was obtained from Food Biotechnology Laboratory collection of Metropolitan Autonomus University (Iztapalapa campus). The cheese was prepared according to González-Olivares et al. (2014) with some modifications. Twenty-four cheeses of $250 \mathrm{~g}$ were made in the School of Agricultural Sciences (ICAp) of the Universidad Autónoma del Estado de Hidalgo from pasteurized and standardized cow's milk (3.6\% of fat content). Twelve cheeses were elaborated with probiotic and agave juice and other twelve without agave juice (control experiment). Milk was heated to a temperature of $36^{\circ} \mathrm{C}$ to add $1 \%$ of probiotic ( $L b$. rhamnosus GG) and $2 \%$ of agave juice. Pre-mature step was performed at $37^{\circ} \mathrm{C}$ for a period of 40 minutes until reaching $18.5^{\circ} \mathrm{D}$. It was added $1 \mathrm{~mL}$ of rennet (CUAMEX) was added. It was curdled for 40 minutes and the curd was cut. It was stirred without heat for 40 minutes and the whey was removed. Curd was divided in molds in a Retamoso-type press (5 kg / kg cheese) during 24 hours. Cheese was vacuum packed (Mukltivac C-100) and it was stored at $14{ }^{\circ} \mathrm{C}$ and $80 \%$ of relative humidity $(\mathrm{RH})$. It was sampled every 7 days during five weeks in aseptic conditions and all experiments were realized in duplicate with independent units.

\subsection{Viability determination}

Viability of Lactobacillus was performed according to González-Olivares et al. (2014). Using plat-count technique. After samples were collected in sterile bags, $10 \mathrm{~g}$ of cheese were dissolved in $90 \mathrm{~mL}$ of sterile peptone water (1\%). Samples were mixed in a Stomacher at $260 \mathrm{rpm}$ during $5 \mathrm{~min}$, obtaining a homogeneous suspension. Then $1 \mathrm{~mL}$ of this suspension was diluted in peptone water (1\%) previously sterilized, considering a final dilution of $1 \times 10^{6}$ and $100 \mu \mathrm{L}$ of each dilution were placed in Petri dishes with MRS agar (Difco) adjusted to pH 5.20 with $0.1 \mathrm{~N}$ acetic acid, so that only Lb. rhamnosus GG grew. Plates were incubated at $37^{\circ} \mathrm{C}$, under anaerobic conditions for $72 \mathrm{~h}$ and the colony forming colonies were reported.

\subsection{Proteolytic profile analysis}

Two different studies of proteolytic profile were carried out to observe the metabolic activity of $L b$. rhamnosus GG during cheese ripening following techniques applied in cheese by González-Olivares et al. (2014). The first study was the determination of free amino groups in order to know the concentration of the peptides produced by the TNBS technique. The second study consisted in the separation of peptides by molecular weight by means of polyacrylamide gel electrophoresis.

\section{Free amino groups determination}

Free amino groups were determined by the 2, 4, 6-trinitrobenzenesulfonic acid method (TNBS). The concentration was determined according to a glycine concentration curve (0.05 to $0.25 \mathrm{mg} / \mathrm{mL})$.

Peptide separation by sodium dodecyl sulfate-polyacrylamide gel electrophoresis (SDS-PAGE)

Denaturing SDS-PAGE at 15\% (w/v) was carried out in order to separate low molecular weight peptides. A broad range (Bio-Rad, USA) molecular weight standard was used. Gels were dyed with Comassie G-250 (Bio-Rad, USA). The molecular weight was estimated and the electrophoretic profiles were analyzed using GelDoc software by BioRad.

\subsection{Sensory analysis}

To find out the effect of the prebiotic (agave juice) addition on cheese flavor and texture, a discrimination test (triangle test) was carried out using a panel of thirty semi-trained panelists (Meilgaard et al., 1999). The samples used for sensory analysis were collected at the end of the ripening process. Two samples (control cheese and cheese prepared with agave juice) were presented to each participant, anonymously and coded with a 3-digit random number. Additionally, an affective test (preference test) was performed in order to determine the influence of such addition on consumers' opinion (Meilgaard et al.,1999). A total of sixty (34 women and 26 men) regular cheese consumers between 30 and 60 years old participated in the preference test. Two samples of cheese (one elaborated with probiotic and agave juice and the other, a commercial semi-ripened Mexican cheese) were presented to the participants. The test was developed in a supermarket near to the dairy section. Participants were selected considering their frequency of consumption of semi and ripened cheeses.

The samples for both sensory tests were served at $5{ }^{\circ} \mathrm{C}$, in cubes of approximately $1 \mathrm{~cm}^{3}$. Unsalted crackers and water were available for mouth rinsing between samples. Results of sensory tests were analyzed at a significance level of $\mathrm{p} \leq 0.01$ ).

\subsection{Statistical analysis}

All experiments, except for the sensory analysis, were performed by triplicate and the experimental data were subjected 
to an analysis of variance (ANOVA), the means comparison was done by the Tuckey's method with a significance level of 0.05 . The program used for the analysis was NCSS-2007 (version: 07-1-15).

\section{Results and discussion}

\subsection{Agave juice analysis}

Carbohydrates present in agave juice were determined and the identification of its compounds was performed by comparing the retention times obtained with the ones of carbohydrates standards. Peaks corresponding to polysaccharides of more than two units were observed at minute 14 , which presented the lowest concentration. At 18 minutes the presence of sucrose was observed, this peak represented the highest concentration of all separated carbohydrates. The total carbohydrate concentration was $7.2 \%$ $(\mathrm{w} / \mathrm{v})$. Fructose and glucose reaching concentrations of $20.27 \%$ and $20.10 \%$ respectively, while di- and poly- saccharides concentration was of $47.45 \%$ for sucrose and $12.17 \%$ for oligosaccharides.

Moreno-Vilet et al. (2017) mentioned that sucrose is the most abundant carbohydrate in agave juice, and glucose and fructose are found in smaller amounts. Additionally, it is known that agave juice is rich in carbohydrates such as inulin, sucrose and fructose in addition to containing small amounts of amino acids and vitamins (Jaimez-Ordaz et al., 2018). On the other hand, agave juice contains a considerable amount of polysaccharides of more than two units, so it can be considered as a prebiotic (Rodríguez-Huezo et al., 2007).

\subsection{Viability}

The probiotic concentration in control cheeses decreased from $9.56 \log \mathrm{CFU} / \mathrm{g}$ to $8.00 \mathrm{logs}$, which represented a difference of 1.5 logarithm cycle. An increase of probiotic amount (two logarithmic cycles) was observed during the first week of ripping in the enriched cheese, maintaining this concentration up to the end of the study (Table 1). In both experiments, the final concentration is higher than that recommended to obtain a beneficial effect (7-8 $\log$ CFU/g) due to its consumption (Karimi et al., 2011). But, in several studies it has been observed that the decrease in the viability of probiotics depends on the strain used and can vary up to 3 cycles (Dinkçi et al., 2019; Sadaghdar et al., 2012).

The death of probiotic in dairy products, like cheeses, is related to the carbon source (oligosaccharides) that stimulate their growth (Farnworth, 2008), which are important promoters of bifidobacteria growth and other kind of probiotics, acting as prebiotic (Kuerman et al., 2020).

Adding prebiotics or potential prebiotic ingredients constitutes a strategy to increase the development and survival of probiotic bacteria in products to which they are incorporated, especially when the development of this kind of microorganisms is difficult (Lourens-Hattingh \& Viljoen, 2001, Siang et al., 2019, Lucatto et al., 2020, Pivetta et al., 2020). On the other hand, non-prebiotic ingredients such as fruit pulp, have been proven in order to increase the probiotic bacteria viability in dairy products (Reeta et al., 2018).
Table 1. Lactobacillus rhamnossus GG viability in a cheese with and without agave juice stored at $14^{\circ} \mathrm{C}$.

\begin{tabular}{ccc}
\hline \multirow{2}{*}{ Time (week) } & \multicolumn{2}{c}{ Probiotic concentration $(\log \mathrm{cfu} / \mathrm{g})$} \\
\cline { 2 - 3 } & With agave juice & Without agave juice \\
\hline 0 & $6.73 \pm 0.07$ & $9.56 \pm 0.11$ \\
1 & $8.73 \pm 0.03$ & $8.47 \pm 0.01$ \\
2 & $8.45 \pm 0.03$ & $8.00 \pm 0.00$ \\
3 & $8.53 \pm 0.14$ & $8.14 \pm 0.06$ \\
4 & $8.70 \pm 0.01$ & $8.01 \pm 0.13$ \\
5 & $8.72 \pm 0.13$ & $8.13 \pm 0.21$ \\
\hline
\end{tabular}

\subsection{Proteolytic activity}

Free amino groups determination

The results of free amino groups determination are observed in Figure 1. In the initial time there was a generation of free amino groups in both analyzed samples. Different amounts of free amino groups were observed in day zero; this may be due to the addition of prebiotics and probiotics before cheese coagulation (pre-ripening process) moment in which proteolysis starts. An increase of amine groups was observed from day 0 to week 2 in both samples, maintaining the concentration until week 5 of storage, getting higher concentration in the added cheese $(8.63 \mathrm{mg} / \mathrm{mL})$ than in the not added $(7 \mathrm{mg} / \mathrm{mL})$.

Peptide fractions are transformed to smaller peptides or even free amino acids by the proteolytic system of the inoculum (Rodríguez-Serrano et al., 2018). In fact, some strains of lactobacilli used as starters modify the free amino acid profile (Di Cagno et al., 2006). This protein degradation sustains the growth of bacteria, since the amount of free amino acids found mainly in milk is insufficient for the optimal growth of the microorganism (Rodríguez-Serrano et al., 2018). Also, due to agave juice composition (sucrose and fructooligosaccharides concentration) probiotic viability was promoted because there is proteolytic enzymes generation (proteinases and peptidases) involved in peptidic fractions release (Lim et al., 2019). This can explain the higher concentration of amine groups in added cheese.

\section{Peptide separation by SDS-PAGE}

There was an accumulation of low molecular weight peptides in both types of cheese, which were not observed at the beginning of ripening. Some high molecular weight peptides could be degraded to small peptides and amino acids by the action of proteases and peptidases (Pérez-Escalante et al., 2018). These kinds of peptides were presented from the first week of ripening and were preserved in subsequent weeks, especially in the cheese with agave juice (Figure 2 and 3 ). The presence of low molecular weight peptides involves the fractionation of caseins. Similarly, peptides between 8.8 and $9.5 \mathrm{kDa}$ could be observed throughout the ripening process, but their concentration decreased during this time. These results showed that the accumulation of low molecular weight peptides is related to the ripening time and 


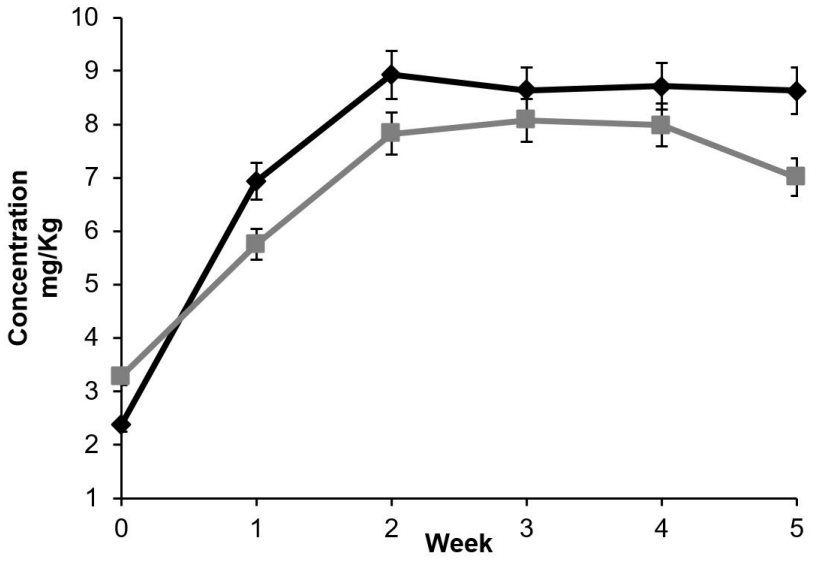

Figure 1. Amine groups concentration during cheese ripening with and without agave juice.

proteolytic activity that the presence of a prebiotic, in this case agave juice, exerts on the probiotic (Jaimez-Ordaz et al., 2018; Martínez-Gutiérrez et al., 2017).

At the end of ripening it was observed the accumulation of low molecular weight peptides in both cheeses (Figure 4).

However, clearly the most observable concentration was that in cheese with agave juice. The production of this kind of peptides is related to both, probiotic survival and agave juice presence, because the proteolytic activity is favored by this potential prebiotic.

The number of microorganisms that survived during the ripening of cheese maintains a high protease activity (Mane \& McSweeney, 2020). Viability results confirmed the presence of probiotic that are related to the metabolic activity. Results of this research are relevant because accumulation of this kind of peptides is related to biological activity, such as antimicrobial and antihypertensive (Moreno-Montoro et al., 2017).

At the same time, accumulation of peptides in dairy products enriched with agave juice has been demonstrated (Martínez-Gutié rrez et al., 2017; Jaimez-Ordaz et al., 2018). However, any study is related with ripening of cheeses and its effect in the addition of agave juice and its relation with prebiotic effect over the proteolytic capacity of probiotics.

\section{Sensory analysis}

\section{Triangle test}

The results showed that the addition of agave juice as prebiotic in the manufacturing of semi-ripened Mexican cheese did not produce any noticeable sensory change. Only 11 panelists out of 30 were able to identify the cheese sample that was different. Thus, according to the results, there were no significant $(\mathrm{p}>0.01)$ differences between the control and the experimental cheese.

\section{Preference Test}

Twenty-eight out of the sixty consumers who evaluated the cheese samples preferred the cheese elaborated with prebiotic.

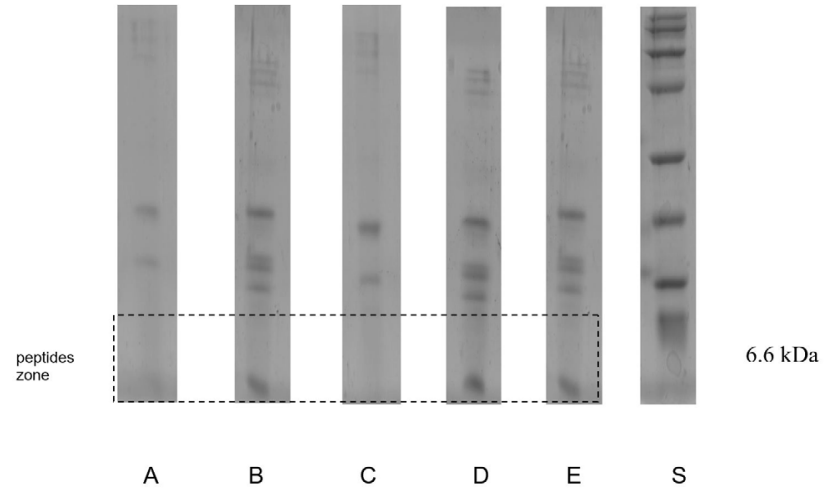

Figure 2. SDS-PAGE peptides separation from semi-ripened cheese without agave juice (A) week 0 of ripening, (B) week 1 of ripening and with agave juice $(\mathrm{C})$ week 0 of ripening, (D) week 1 of ripening, (E) week 2 of ripening $(S)$ broad range standard.

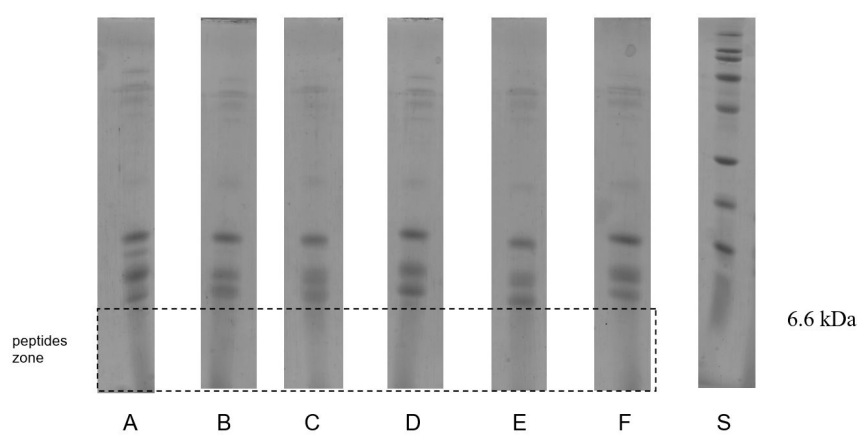

Figure 3. SDS-PAGE peptides separation from semi-ripened cheese without agave juice (A) week 2 of ripening, (B) week 3 of ripening, (C) week 4 of ripening and with agave juice (D) week 3 of ripening, (E) week 4 of ripening, (F) week 5; of ripening (S) broad range standard.

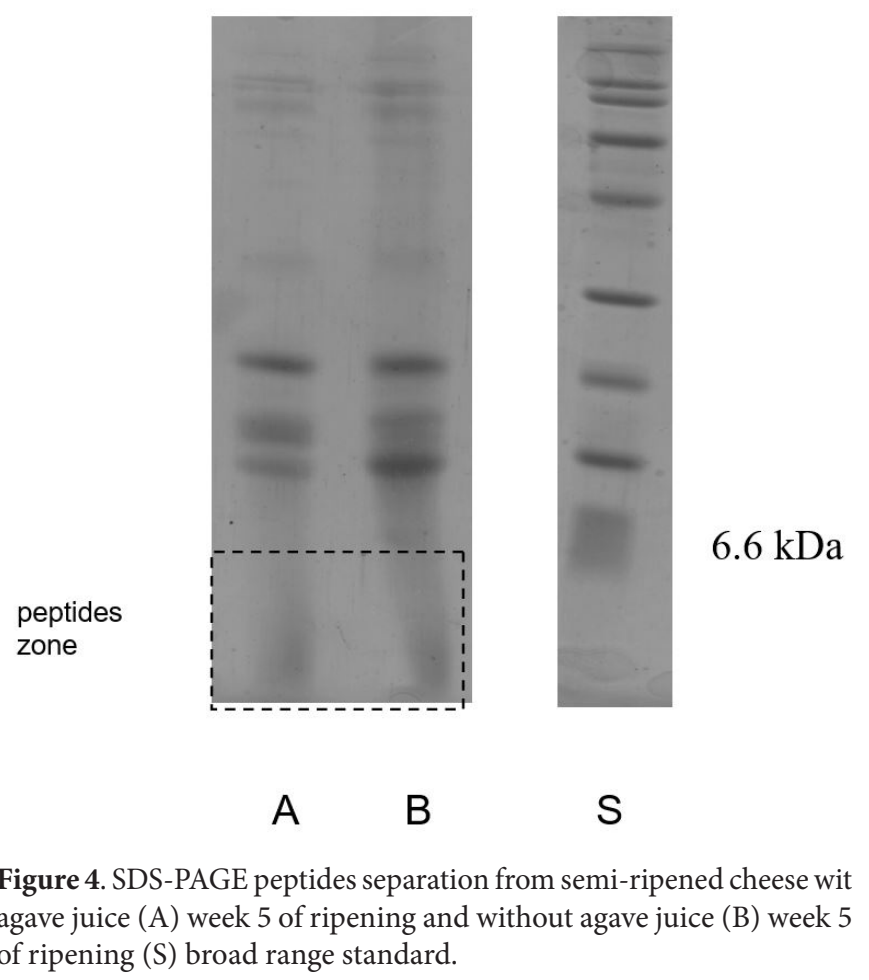


This result indicated that there was no significant preference $(\mathrm{p}>0.01)$ between the experimental and the commercial cheese among the participants. Indeed, it can be assumed that using agave juice, as ingredient for the elaboration of semi-ripened cheese did not had any negative effect. From the point of view of the group of regular semi-ripened cheese consumers, the sensory properties of both cheeses were similar. It is remarkable due to the impact of sensory characteristics such as the taste and aroma of foods on consumer acceptance (Simmering \& Blaut, 2001; Stanton et al., 2001). The result observed is in agreement with those reported by Azambuja et al. (2013) and Zamora-Vega et al. (2013) in preference tests carried out for fresh and ripened cheeses, respectively, with the addition of probiotic and prebiotic ingredients. Those authors observed no effect on the taste, color and odor of the experimental cheeses. Nevertheless, it has also been reported positive changes in sensory properties derived by the addition of probiotics (Akarca, 2020) as well as the use of fruit juices to improve the acceptability of dairy products containing probiotics (Ryan et al., 2020).

The use of agave juice as a prebiotic ingredient allowed the elaboration of a semi-ripened Mexican cheese, improving survival of the probiotic used as starter and activating its proteolytic system without negatively affecting the sensory characteristics of the final product. However, in the same way of Ryan et al. (2020) recommendation, sensory evaluations using trained panelists would be highly beneficial in the commercialization process of probiotic dairy products.

\section{Conclusion}

Agave juice is a promising raw material to be used in the manufacturing of semi-ripened Mexican cheese. This carbon source promotes the survival of Lactobacillus rhamnosus GG having a direct influence on their proteolytic activity and generating a higher concentration of free amino groups. Moreover, this probiotic releases a higher amount of low molecular weight peptides throughout the ripening process in the presence of agave juice, which allowed the elaboration of a product similar to a commercial one.

Our results highlight that dairy matrices as semi-ripened cheese, represent an opportunity in food science and technology, especially to develop foods with nutritional benefits for the health of consumers by adding pre- and probiotics. Nevertheless, since there are few reports similar to our experiments, further research would be necessary to analyze the effect of the addition of agave juice in semi-ripened cheese using a bigger group of consumers.

\section{References}

Akarca, G. (2020). Lipolysis and aroma occurrence in Erzincan Tulum cheese, which is produced by adding probiotic bacteria and ripened in various packages. Food Science and Technology, 40(1), 102-116. http://dx.doi.org/10.1590/fst.33818.

Azambuja, N. C., Zacarchenco, P. B., Fleuri, K. F., Andrade, J. C., Moreno, I., Van Dender, A. G. F., \& Gallina, D. A. (2013). Characterization of fresh cheese with addition of probiotics and prebiotics. Journal of Life Science, 7(2), 189-195.

Chen, M. J., Tang, H. Y., \& Chiang, M. L. (2017). Effects of heat, cold, acid and bile salt adaptations on the stress tolerance and protein expression of kefirisolated probiotic Lactobacillus kefiranofaciens M1. Food Microbiology, 66, 20-27. http://dx.doi.org/10.1016/j.fm.2017.03.020. PMid:28576369.
Chung, B., \& Kamal-Eldin, A. (2020). Bioactive compounds produced by probiotics in food products. Current Opinion in Food Science, 32, 76-82. http://dx.doi.org/10.1016/j.cofs.2020.02.003.

Costa, G. M., Paula, M. M., Barao, C. E., Klososki, S. J., Bonafe, E. G., Visentainer, J. V., Cruz, A. G., \& Pimentel, T. C. (2019). Yoghurt added with Lactobacillus casei and sweetened with natural sweeteners and/or prebiotics: Implications on quality parameters and probiotic survival. International Dairy Journal, 97, 139-148. http://dx.doi. org/10.1016/j.idairyj.2019.05.007.

Di Cagno, R., Quinto, M., Corsetti, A., Minervini, F., \& Gobbetti, M. (2006). Assessing the proteolytic and lipolytic activities of single strains of mesophilic lactobacilli as adjunct cultures using a Caciotta cheese model system. International Dairy Journal, 16(2), 119-130. http://dx.doi.org/10.1016/j.idairyj.2005.01.012.

Dinkçi, N., Akdeniz, V., \& Akalin, S. (2019). Survival of probiotics in functional foods during shelf life. In C. M. Galanakis (Ed.), Food Quality and Shelf Life (pp. 201-233). Amsterdam: Elsevier. http:// dx.doi.org/10.1016/B978-0-12-817190-5.00006-9.

Farnworth, E. (2008). Handbookof Fermented Functional Foods (pp 236). Quebec: CRC Press. http://dx.doi.org/10.1201/9781420053289.

González-Olivares, L. G., López-Cuellar, Z. L., \& Añorve-Morga, J. (2014). Viability and proteolytic capacity of Lactobacillus bulgaricus 2772 and Lactobacillus rhamnosus GG during cheese ripening. Journal of Biosciences and Medicines, 2(3), 7-12. http://dx.doi.org/10.4236/jbm.2014.23002.

Grom, L. C., Rocha, R. S., Balthazar, C. F., Guimaraes, Z. T., Coutinho, N. M., Barros, C. P., Pimentel, T. C., Venancio, E. L., Collopy-Junior, I., Maciel, P. M. C., Silva, P. H. F., Granato, D., Freitas, M. Q., Esmerino, E. A., Silva, M. C., \& Cruz, A. G. (2020). Postprandial glycemia in healthy subjects: Which probiotic dairy food is more adequate? Journal of Dairy Science, 103(2), 110-1119. http://dx.doi. org/10.3168/jds.2019-17401. PMid:31785881.

Guarner, F., Khan, A. G., Garisch, J., Eliakim, R., Gangl, A., Thomson, A., Krabshuis, J., Lemair, T., Kaufmann, P., de Paula, J. A., Fedorak, R., Shanahan, F., Sanders, M. E., Szajewska, H., Ramakrishna, B. S., Karakan, T., \& Kim, N. (2012). World Gastroenterology Organisation Global Guidelines: Probiotics and Prebiotics. Journal of Clinical Gastroenterology, 46(6), 468-481. http://dx.doi.org/10.1097/ MCG.0b013e3182549092. PMid:22688142.

Jaimez-Ordaz, J., Martínez-Ramírez, X., Cruz-Guerrero, A. E., ContrerasLópez, E., Ayala-Niño, A., Castro-Rosas, J., \& González-Olivares, L. G. (2018). Survival and proteolytic capacity of probiotics in a fermented milk enriched with agave juice and stored in refrigeration. Food Science and Technology, 39(1), 188-194. http://dx.doi.org/10.1590/fst.41117.

Karimi, R., Mortazavian, A. M., \& Da Cruz, A. G. (2011). Viability of probiotic microorganisms in cheese during production and storage: a review. Dairy Science \& Technology, 91(3), 283-308. http://dx.doi. org/10.1007/s13594-011-0005-X.

Kuerman, M., Bao, Y., Guo, Y., \& Guo, M. (2020). Effects of prebiotic carbohydrates on the growth promotion and cholesterol- lowering abilities of compound probiotics in vitro. Lebensmittel-Wissenschaft + Technologie, 118, 108703. http://dx.doi.org/10.1016/j.lwt.2019.108703.

Lim, Y. H., Foo, H. L., Loh, T. C., Mohamad, R., \& Abdullah, N. (2019). Comparative studies of versatile extracellular proteolytic activities of lactic acid bacteria and their potential for extracellular amino acid productions as feed supplements. Journal of Animal Science and Biotechnology, 10(15), 1-13. http://dx.doi.org/10.1186/s40104019-0323-z. PMid:30886709.

Lourens-Hattingh, A., \& Viljoen, B. (2001). Yogurt as probiotic carrier food. International Dairy Journal, 11(1-2), 1-17. http://dx.doi. org/10.1016/S0958-6946(01)00036-X. 
Lucatto, J. N., da Silva-Buzanello, R. A., Terroso-Gama de Menzoza, S. N., Lazarotto, T. C., Sanchez, J. L., Bona, E., \& Drunkler, D. A. (2020). Performance of different microbial cultures in potentially probiotic and prebiotic yoghurts from cow and goat milks. International Journal of Dairy Technology, 70(1), 144-156. http:// dx.doi.org/10.1111/1471-0307.12655.

Mane, A., \& McSweeney, P. L. H. (2020). Proteolysis in Irish farmhouse Camembert cheese during ripening. Journal of Food Biochemistry, 44(1), e13101. http://dx.doi.org/10.1111/jfbc.13101. PMid:31782198.

Martínez-Gutiérrez, F., Ratering, S., Juárez-Flores, B., Godinez-Hernandez, C., Geissler-Plaum, R., Prell, F., Zorn, H., Czermak, P., \& Schnell, S. (2017). Potential use of Agave salmiana as a prebiotic that stimulates the growth of probiotic bacteria. Lebensmittel-Wissenschaft + Technologie, 84, 151-159. http://dx.doi.org/10.1016/j.lwt.2017.05.044.

Meilgaard, M., Vance Civille, G., \& Thomas Carr, B. (1999). Sensory evaluation techniques. New York, USA: CRC Press. http://dx.doi. org/10.1201/9781439832271.

Moreno-Montoro, M., Olalla-Herrera, M., Rufián-Henares, J. Á., Martínez, R. G., Miralles, B., Bergillos, T., Navarro-Alarcón, M., \& Jauregi, P. (2017). Antioxidant, ACE-inhibitory and antimicrobial activity of fermented goat milk: activity and physicochemical property relationship of the peptide components. Food \& Function, 8(8), 2783-2791. http://dx.doi.org/10.1039/C7FO00666G. PMid:28702643.

Moreno-Vilet, L., Bostyn, S., Flores-Montaño, J. L., \& CamachoRuiz, R. M. (2017). Size-exclusion chromatography (HPLC-SEC) technique optimization by simplex method to estimate molecular weight distribution of agave fructans. Food Chemistry, 237, 833-840. http://dx.doi.org/10.1016/j.foodchem.2017.06.020. PMid:28764075.

Orsi, C., \& Zambrini, A. V. (2017). Probiotics and prebiotics. In F. Conto (Ed.) Advances in Dairy products (pp. 37-57) Hoboken, New Jersey: Jhon Wiley and Sons Ltd. http://dx.doi. org/10.1002/9781118906460.ch1c.

Pérez-Escalante, E., Jaimez-Ordaz, J., Castañeda-Ovando, A., ContrerasLópez, E., Añorve-Morga, J., \& González-Olivares, L. G. (2018). Antithrombotic activity of milk protein hydrolysates by lactic acid bacteria isolated from commercial fermented milks. Brazilian Archives of Biology and Technology, 61(e18180132), 1-10. http:// dx.doi.org/10.1590/1678-4324-2018180132.

Pivetta, F. P., da Silva, M. N., Tagliapietra, B. L., \& Richards, N. S. S. (2020). Addition of green banana biomass as partial substitute for fat and encapsulated Lactobacillus acidophilus in requeijão cremoso processed cheese. Food Science and Technology (Campinas), 40(2), 451-457. http://dx.doi.org/10.1590/fst.03919.

Prezzi, L. E., Lee, S. H. I., Nunes, V. M. R., Corassin, C. H., Pimentel, T. C., Rocha, R. S., Ramos, G. L. P. A., Guimaraes, J. T., Balthazar, C. F., Duarte, M. C. K. H., Freitas, M. Q., Esmerino, E. A., Silva, M. C., Cruz, A. G., \& Oliveira, C. A. F. (2020). Effect of Lactobacillus rhamnosus on growth of Listeria monocytogenes and Staphylococcus aureus in a probiotic Minas Frescal cheese. Food Microbiology, 92, 103557. http://dx.doi.org/10.1016/j.fm.2020.103557. PMid:32950151.

Quigley, E. M. M. (2019). Prebiotics and Probiotics in Digestive Health. Clinical Gastroenterology and Hepatology, 17(2), 333-344. http:// dx.doi.org/10.1016/j.cgh.2018.09.028. PMid:30267869.

Reeta, K., Kumar, S., Rasane, P., \& Nimmanapalli, R. (2018). Optimisation of a process for production of pomegranate pulp and flaxseed powder fortified probiotic Greek dahi. International Journal of Dairy Technology, 71(3), 753-763. http://dx.doi.org/10.1111/14710307.12494.

Rodríguez-Huezo, M. E., Durán-Lugo, R., Prado-Barragán, L. A., CruzSosa, F., Lobato-Calleros, C., Alvarez-Ramírez, J., \& Vernon-Carter, E. J. (2007). Pre-selection of protective colloids for enhanced viability of Bifidobacteriumbifidum following spray-drying and storage, and evaluation of aguamiel as thermoprotective prebiotic. Food Research International, 40(10), 299-1306. http://dx.doi.org/10.1016/j. foodres.2007.09.001.

Rodríguez-Serrano, G. M., García-Garibay, M., Cruz-Guerrero, A. E., Gómez-Ruiz, L., Ayala-Niño, A., Castañeda-Ovando, A., \& GonzálezOlivares, L. G. (2018). Proteolytic system of Streptococcus thermophiles. Journal of Microbiology and Biotechnology, 28(10), 1581-1588. http:// dx.doi.org/10.4014/jmb.1807.07017. PMid:30196594.

Ryan, J., Hutchings, S. C., Fang, Z., Bandara, N., Gamlath, S., Ajlouni, S., \& Ranadheera, C. S. (2020). Microbial, physico-chemical and sensory characteristics of mango juice-enriched probiotic dairy drinks. International Journal of Dairy Technology, 73(1), 182-190. http://dx.doi.org/10.1111/1471-0307.12630.

Sadaghdar, Y., Mortazavian, A. M., \& Ehsani, M. R. (2012). Survival and activity of 5 Probiotic Lactobacilli strains in 2 types of Flavored Fermented Milk. Food Science and Biotechnology, 21(1), 51-157. http://dx.doi.org/10.1007/s10068-012-0019-z.

Sanders, M. E., Merenstein, D. J., Reid, G., Gibson, G. R., \& Rastall, R. A. (2019). Probiotics and prebiotics in intestinal health and disease: from biology to the clinic. Nature Reviews. Gastroenterology \& Hepatology, 16(10), 605-616. http://dx.doi.org/10.1038/s41575-019-0173-3. PMid:31296969.

Sarfraz, F., Farooq, U., Shafi, A., Hayat, Z., Akram, K., \& Rehman, H. (2019). Hypolipidaemic effects of synbiotic yoghurt in rabbits. International Journal of Dairy Technology, 72(4), 545-550. http:// dx.doi.org/10.1111/1471-0307.12618.

Shafi, A., Raja, H. M., Farooq, U., Akram, K., Hayat, Z., Naz, A., \& Nadeem, H. R. (2019). Antimicrobial and antidiabetic potential of synbiotic fermented milk: A functional dairy product. International Journal of Dairy Technology, 72(1), 15-22. http://dx.doi.org/10.1111/14710307.12555.

Siang, S. C., Wai, L. K., Lin, N. K., \& Phing, P. L. (2019). Effect of added prebiotic (Isomalto-oligosaccharide) and coating of beads on the survival of microencapsulated Lactobacillus rhamnosus GG. Food Science and Technology (Campinas), 39(S-2, Suppl. 2), 601-609. http://dx.doi.org/10.1590/fst.27518.

Simmering, R., \& Blaut, M. (2001). Pro- and pre-biotics the tasty guardian angels. Applied Microbiology and Biotechnology, 55(1), 19-28. http://dx.doi.org/10.1007/s002530000512. PMid:11234954.

Stanton, C., Gardiner, G., Meehan, H., Collins, K., Fitzgerald, G., Lynch, P. B., \& Ross, R. P. (2001). Market potential for probiotics. Supplement of American Journal of Clinical Nutrition, 73(2, Suppl.), 476S-483S. http://dx.doi.org/10.1093/ajcn/73.2.476s. PMid:11157361.

Vinderola, G., Reinheimer, J., \& Salminen, S. (2019). The enumeration of probiotic issues: From unavailable standardised culture media to a recommended procedure? International Dairy Journal, 96, 58-65. http://dx.doi.org/10.1016/j.idairyj.2019.04.010.

Zamora-Vega, R., Montañez-Soto, J. L., Venegas-González, J., Bernardino-Nicanor, A., Cruz, L. G., \& Martínez-Flores, H. E. (2013). Development and characterization of a symbiotic cheese added with Saccharomyces boulardii and inulin. African Journal of Microbiological Research, 7(23), 2828-2834. http://dx.doi.org/10.5897/ AJMR2013.5566.

Zendeboodi, F., Khorshidian, N., Mortazavian, A. M., \& Cruz, A. G. (2020). Probiotic: conceptualization from a new approach. Current Opinion in Food Science, 32, 103-123. http://dx.doi.org/10.1016/j. cofs.2020.03.009. 